\title{
Status and the Evaluation of Workplace Deviance
}

\section{Citation}

Bowles, Hannah Riley, and Michele Gelfand. 2010. “Status and the Evaluation of Workplace Deviance." Psychological Science 21 (1): 49-54. doi:10.1177/0956797609356509.

\section{Permanent link}

http://nrs.harvard.edu/urn-3:HUL.InstRepos:38036038

\section{Terms of Use}

This article was downloaded from Harvard University's DASH repository, and is made available under the terms and conditions applicable to Open Access Policy Articles, as set forth at http:// nrs.harvard.edu/urn-3:HUL.InstRepos:dash.current.terms-of-use\#OAP

\section{Share Your Story}

The Harvard community has made this article openly available.

Please share how this access benefits you. Submit a story.

Accessibility 
Running head: STATUS AND WORKPLACE DEVIANCE

\title{
Status and the Evaluation of Workplace Deviance
}

\author{
Hannah Riley Bowles \\ Harvard University \\ John F. Kennedy School of Government \\ 79 JFK Street, Cambridge, MA 02138 \\ Tel: 6174964717 \\ Email: hannah_bowles@harvard.edu \\ Michele Gelfand \\ University of Maryland, Department of Psychology
}

Forthcoming in Psychological Science.

Please do not quote or cite without permission of authors 


\begin{abstract}
Bias in the evaluation of workplace misbehavior is hotly debated in courts and corporations, but it has received little empirical attention. Classic sociological literature suggests that deviance by lower (vs. higher) status actors will be evaluated more harshly. However, more recent psychological literature suggests that discrimination in the evaluation of misbehavior may be moderated by the relative status of the evaluator because status influences both rule observance and attitudes toward social hierarchy. In Study 1, the psychological experience of higher status decreased rule observance and increased preferences for social hierarchy, as theorized. In three subsequent experiments, we tested the hypothesis that higher status evaluators would be more discriminating in their evaluations of workplace misbehavior, evaluating fellow higher status deviants more leniently. Results supported the hypothesized interaction effect of evaluator status and target status on the evaluation of workplace deviance based on achieved (Study $2 \mathrm{a} / \mathrm{b}$ ) and ascribed (Study 3) status characteristics.
\end{abstract}




\section{Status and the Evaluation of Workplace Deviance}

Threatening the largest civil rights class-action suit in American history, Betty Dukes seeks to represent 1.6-million female employees of Wal-Mart in a sex discrimination charge (Dukes vs. Wal-Mart). One claim she makes is that managers disciplined female employees for behaviors tolerated from male employees (e.g., returning late from breaks) and that sex-discriminatory disciplinary actions impeded women's advancement. In spite of active debate in courts and corporate corridors, academics have paid little attention to questions of bias in the evaluation of workplace misbehavior.

Scholars of workplace deviance acknowledge that evaluations of norm-violating behaviors are fundamentally subjective (Bennett \& Robinson, 2003; Giacalone \& Greenberg, 1997) and shaped by dominant coalitions within organizations (Bennett, Aquino, Reed, \& Thau, 2005). Yet, the emphasis within this blossoming field has been on validating the construct (Dalal, 2005; Robinson \& Bennett, 1995), identifying its antecedents and consequences (Bennett \& Robinson, 2003; Berry, Ones, \& Sackett, 2007), and proposing preventive measures (Fox \& Spector, 2005; Vardi \& Weitz, 2004). We argue that more attention should be paid to the subjectivity in workplace deviance, in part because of the potential for discrimination, but, more importantly, because it helps to illuminate another way in which psychological processes reinforce status hierarchies in organizations.

\section{EVALUATING DEVIANCE}

Sociologists have long argued that greater conformity to group norms is demanded of those of lower social status (Hollander, 1958; Homans, 1950) and that the labeling of "deviant" behavior is a tool for those of higher status to maintain their dominance (Marx \& Engels, 1994). Studying “social outsiders," Becker (1963) demonstrated how lower status actors receive more severe 
social sanctions for the same rule infractions. Focusing on gender, Schur (1983) elucidated how women's lower status relative to men makes them more vulnerable to the "deviant" label, and how this threat of being labeled reinforces women's social subordination.

This sociological research suggests a main effect of target status on the evaluation of workplace deviance with lower status actors being evaluating more harshly than higher status actors. However, more recent psychological research suggests that evaluator status may moderate this classic target-status effect, such that the biasing effect of the deviant's status is greater with higher than lower status evaluators.

Research on the psychology of social dominance shows that members of higher status social groups (e.g., men vs. women, racial majorities vs. minorities) tend to espouse more hierarchy-enhancing beliefs, such as that some are more deserving of privileges than others. In contrast, members of lower status social groups tend to espouse more status-attenuating beliefs, such as embracing ideals of equal treatment (Sidanius \& Pratto, 2001). Similarly, research on ingroup bias indicates that high-status groups display greater in-group favoritism than do lowstatus groups, presumably because those of higher status have greater motivation to preserve their place in the social hierarchy (Bettencourt, Charlton, Dorr, \& Hume, 2001; Mullen, Brown, \& Smith, 1992; Pettigrew, 1979).

Status also influences the propensity toward rule abidance, specifically, because higher social status generally permits greater self-direction in one's behavior and pursuits (Hollander, 1958; Kohn, 1977). Lower status groups are socialized to greater conformity and, as a result, tend to be more strictly rule oriented with regard to discipline (Kohn, 1977). Even just the psychological experience of being in a lower power position makes actors conform more to 
social norms (Galinsky, Magee, Gruenfeld, Whitson, \& Liljenquist, 2008; Keltner, Gruenfeld, \& Anderson, 2003).

In sum, we hypothesize an interaction effect of evaluator status and target status on the evaluation of workplace deviance. We predict that members of higher status groups will be more discriminating in their evaluations and more lenient toward misbehavior by members of highthan low-status groups_consciously or unconsciously protecting their privileged status. We tested this hypothesis in two sets of studies based on achieved-status (Studies $2 \mathrm{a} / \mathrm{b}$ ) and ascribedstatus (Study 3) characteristics, but first we examined whether the psychological experience of status has the theorized effects on social dominance and rule observance.

\section{STUDY 1:}

\section{EFFECT OF STATUS ON RULE COMPLIANCE AND SOCIAL DOMINANCE}

\section{Method}

\section{Participants and Design}

Two-hundred-and-fifteen American adults with work experience (107 men, 108 women; $M$ work experience $=11.83$ years) completed an online survey through a market-research firm.

Participants were randomly assigned to high- or low-status conditions.

\section{Procedure}

Participants completed a two-part survey. In Part I, we manipulated the psychological experience of status using an adapted version of Galinsky, Gruenfeld, and Magee's (2003) psychological experience of power. Our manipulation emphasized "the amount of respect accorded by others" as opposed to control over others (see Magee \& Galinsky, 2008 on status vs. power, p. 359). We asked participants to reflect on a situation in which "others looked up to you and deferred to your opinion" or "you looked up to others and deferred to their opinion" because "you were in a 
[high/low]-ranking position" or "[had a lot of/lacked] experience or competence." In Part II, participants answered questions about how they would behave and feel in a, correspondingly, high- or low-status role at work (i.e., executive vs. entry-level position). The questions included a three-item measure of rule compliance from the "dutifulness" subcomponent of the Big-Five (Goldberg, 1990) ("follow directions," "stick to the rules," "disregard the rules" [reverse coded]) and an eight-item measure of social dominance adapted from Pratto, Sidanius, Stallworth, and Malle (1994) (e.g., "some employees are just more worthy than others of recognition," "it is important that we treat other employees as equals" [reverse coded]).

\section{Results}

The results supported the theorized effects of the psychological experience of status on rule orientation and social dominance. Participants in the high-status (vs. low-status) condition reported lower rule compliance (high $M=5.71, S D=1.05$, low $M=6.26, S D=.83, t[213]=$ 4.26, $p<.001, d=.58$ ) and higher social dominance (high $M=3.32, S D=1.11$, low $M=2.93$, $S D=.99, t[213]=2.75, p<.01, d=.38)$.

\section{STUDY 2A:}

\section{EFFECT OF ACHIEVED STATUS ON EVALUATION OF WORKPLACE DEVIANCE}

In Study 2a, we tested whether the psychological experience of status would influence evaluations of workplace misbehavior by high- and low-status targets. We manipulated target status based on organizational standing (rank, tenure) and regard (professional accomplishment), which are classic indicators of social status (Berger, Fisek, Norman, \& Zelditch, 1977; Hollander, 1958). 


\section{Method}

\section{Participants and Design}

Two-hundred-and-eighty-one American adults with work experience (138 men, 143 women; $M$ work experience $=16.85$ years) completed an online survey through a market-research firm. Participants were randomly assigned to conditions in a 2(Evaluator Status) $\times 2$ (Target Status) between-subjects design.

\section{Procedure}

Participants completed a two-part survey. Part I was the manipulation of evaluator status (same as described in Study 1). In Part II, participants evaluated a male employee who had been “mailing personal letters and packages at the company's expense." The employee was described either as a "well-regarded" executive with a long track record of performance (high-status target) or a "not well-known" staff assistant with little track record (low-status target).

Participants indicated on five seven-point agree-disagree scales how the employee's boss should respond to his behavior (“...take some kind of formal action against him [e.g., formal reprimand, punishment]," “...give him the benefit of the doubt..." [reverse coded], “...deal with the situation privately and informally" [reverse coded], "this behavior should be punished," "this behavior would not worry me personally" [reverse coded]). We combined these measures into a mean composite of "the propensity to punish" $(\alpha=.76)$.

\section{Results}

Participants in the high-status (vs. low-status) target condition rated the employee as higher ranking (seven-point scale: high $M=5.04, S D=.96$, low $M=2.61, S D=1.00, t[279]=20.42, p$ $<.001, d=2.45)$. ANOVA of the propensity to punish showed no main effect for evaluator status $\left(F[1,277]=0.34, p=.56, \eta^{2}=.001\right)$, a significant main effect for target status $(F[1,277]$ 
$=4.41, p=.04, \eta^{2}=.02$ ), and a significant interaction effect of Evaluator Status $\times$ Target Status $\left(F[1,277]=8.44, p<.01, \eta^{2}=.03\right)$. As the left-hand panel of Figure 1 illustrates, the results supported our predictions. High-status evaluators were more inclined to punish the low- than high-status target $(t[144]=3.54, p<.001, d=.59)$, whereas low-status evaluators were prone to equal treatment $(t[133]=0.57, p=.57, d=.10)$.

\section{STUDY 2B:}

\section{EFFECT OF ACHIEVED STATUS ON EVALUATION OF WORKPLACE DEVIANCE}

Study $2 \mathrm{~b}$ was a replication of Study $2 \mathrm{a}$, restricting the manipulation of target status to high or low professional regard.

\section{Method}

\section{Participants and Design}

Participants were 174 American adults with work experience (76 men, 98 women; $M$ work experience $=17.15$ years $)$.

\section{Procedure}

The procedure was the same as in Study 2a, with the exception that the target was an IT Manager who had "a strong track record" and was "very well regarded...for his technical expertise" (highstatus target) or who had "little track record" and "not...much of a reputation for technical expertise" (low-status target).

\section{Results}

Participants in the high-status (vs. low-status) target condition rated the employee as held in higher regard (seven-point scale: high $M=5.78, S D=1.57$, low $M=2.41, S D=1.17, t[172]=$ $15.87, p<.001, d=2.45)$. ANOVA of the propensity-to-punish composite $(\alpha=.75)$ showed no main effect for evaluator status $\left(F[1,170]=0.86, p=.36, \eta^{2}=.01\right)$, a significant main effect for 
target status $\left(F[1,170]=6.34, p=.01, \eta^{2}=.04\right)$, and a significant interaction effect of Evaluator Status $\times$ Target Status $\left(F[1,170]=3.95, p<.05, \eta^{2}=.02\right)$. As the right-hand panel in Figure 1 illustrates, high-status evaluators again were more inclined to punish the low- than high-status target $(t[85]=3.37, p=.001, d=.73)$, whereas low-status evaluators were not $(t[85]=0.36, p=$ $.72, d=.08)$.

\section{STUDY 3:}

\section{EFFECT OF ASCRIBED STATUS ON EVALUATION OF WORKPLACE DEVIANCE}

In Study 3, we tested our hypotheses on a range of behaviors previously validated as examples of workplace deviance. Taking inspiration from Dukes vs. Wal-Mart, we also tested whether the pattern of effects observed in Studies 2a/b would apply to ascribed status categories (viz., gender, race). Gender and race are classic examples of diffuse status characteristics, with men generally ascribed higher status than women (Eagly \& Wood, 1982; Ridgeway, 2001) and Whites higher status than Blacks (Berger, et al., 1977; Sidanius \& Pratto, 2001).

\section{Method}

\section{Participants and Design}

One-hundred-and-fifty-nine White American adults with work experience (43 men, 116 women; $M$ work experience $=15.48$ years $)$ completed an online survey. Participants were randomly assigned to one of four target-identity conditions in a 2(Evaluator Gender: Male/Female) $\times$ 2(Target Race: White/Black) × 2(Target Gender: Male/Female) design.

\section{Procedure}

Participants adopted the role of managers evaluating an employee. Materials indicated the employee had a college degree, work experience, and good performance record. Participants were instructed to evaluate ten deviant workplace behaviors, treating each one as if it was the 
only negative information they had about the employee. For each behavior, participants indicated their agreement on a seven-point scale with the statements "this behavior represents a serious violation" and "this behavior should be punished."

The ten behaviors were drawn from Robinson and Bennett's (1995) typology of workplace deviance and were representative of "major" acts of workplace deviance according to their multi-dimensional scaling map: went against boss's decision, covered up mistakes, lied about hours worked, recklessly endangered co-workers, sexually harassed co-worker, stole equipment/merchandise, stole co-worker's possessions, verbally abused customer, and physically abused customer (listed in order of seriousness). We presented the behaviors in two random orders across conditions, and observed no order effects.

We manipulated target gender using stereotypically male and female names and pronouns. We manipulated target race using Black- and White-identified names across sex (Black: Jamal/Latoya; White: Greg/Kristen) (see Bertrand \& Mullainathan, 2004). For example, “Jamal went against his boss' decision.” After completing their evaluations, all participants in the sample categorized the target's gender and race as intended.

\section{Results}

The serious and punish ratings were strongly correlated (mean $r=.62$ ), so we averaged the ratings for each behavior and then combined them into one overall mean composite of the propensity to punish workplace deviance $(\alpha=.76)$. We observed significant main effects for target gender $\left(F[1,151]=5.76, p=.02, \eta^{2}=.04\right)$ and target race $\left(F[1,151]=5.84, p=.02, \eta^{2}=\right.$ .04). These main effects were qualified by two-way interaction effects of Evaluator Gender $\times$ Target Gender $\left(F[1,151]=4.99, p=.03, \eta^{2}=.03\right)$ and Evaluator Gender $\times$ Target Race $(F[1$, $\left.151]=6.41, p=.01, \eta^{2}=.04\right)$. No other effects were significant $(F \mathrm{~s}<0.85)$. 
As the top of Figure 2 illustrates, the results supported our predictions. White men evaluated male deviance more leniently than female deviance $\left(F[1,40]=6.04, p=.02, \eta^{2}=.13\right)$ and White deviance more leniently than Black deviance $\left(F[1,40]=6.62, p=.01, \eta^{2}=.14\right)$. In contrast, White female evaluators demonstrated more equal treatment $(F \mathrm{~s}<0.04)$.

To explore whether the female evaluators' lack of bias might be explained by a ceiling effect, we replicated our analyses on composite evaluations of the three least and most serious behaviors (as listed in Methods). As the bottom of Figure 2 illustrates, the interaction effects remained significant for the least and most serious behaviors $\left(F s \geq 4.33, p<.04, \eta^{2} \geq .04\right)$, and there was no shift in the evenhandedness of women's evaluations.

\section{GENERAL DISCUSSION}

These experimental results support claims that status-linked social identities, such as gender, do indeed color the evaluation of workplace deviance. Consistent with classic sociological theory, we find evidence that biases in the evaluation of workplace deviance reinforce the social hierarchy by granting more lenience to those of higher status. However, the status of the evaluator moderated this effect: those of higher status were significantly more prone to biased evaluation of misbehavior than those of lower status.

These findings have important implications for research and practice. They challenge scholars to explore more systematically the subjective labeling of deviance in the workplace. They contribute theoretically to the integration of sociological and psychological perspectives on status and the reinforcement of social hierarchy. For organizations and the courts, they suggest an explanation for hotly debated claims of discrimination in the evaluation of workplace misbehavior. 
These studies are, however, just a starting point. Future field research could investigate how such biases manifest themselves in organizational outcomes. Future experimental research could test for boundary conditions, such as when deviance evokes specific status-linked stereotypes (Fragale, Rosen, Xu, \& Merideth, 2009), transgresses central values of one's status category (Marques, Yzerbyt, \& Leyens, 1988), or has different consequences depending on the deviant's status (Giordano, 1983). There is rich potential in exploring the gray areas of workplace misbehavior - for understanding the psychology of norm conformity as well as the reinforcement of social hierarchy.

Acknowledgements - The authors thank Harvard Kennedy School's Center for Public Leadership and Women and Public Policy Program and the University of Maryland for funding this research. 


\section{REFERENCES}

Bennett, R. J., Aquino, K., Reed, A. I., \& Thau, S. (2005). The normative nature of employee deviance and the impact of moral identity. In S. Fox \& P. Spector (Eds.), Counterproductive work behavior: Investigations of actors and targets (pp. 107-125). Washington, DC: American Psychological Association.

Bennett, R. J., \& Robinson, S. L. (2003). The past, present and future of workplace deviance research. In J. Greenberg (Ed.), Organizational behavior: The state of the science (2nd ed., pp. 247-281). Mahwah, NJ: Lawrence Erlbaum.

Berger, J., Fisek, M. H., Norman, R. Z., \& Zelditch, M. E. (1977). Status characteristics and social interaction: An expectation-states approach. New York: Elsevier.

Berry, C. M., Ones, D. S., \& Sackett, P. R. (2007). Interpersonal deviance, organizational deviance, and their common correlates: A review and meta-analysis. Journal of Applied Psychology, 92, 410-424.

Bertrand, M., \& Mullainathan, S. (2004). Are Emily and Greg more employable than Lakisha and Jamal? A field experiment on labor market discrimination. American Economic Review, 94, 991-1013.

Bettencourt, B. A., Charlton, K., Dorr, N., \& Hume, D. L. (2001). Status differences and ingroup bias: A meta-analytic examination of the effects of status stability, status legitimacy, and group permeability. Psychological Bulletin, 127, 520-542.

Dalal, R. S. (2005). A Meta-analysis of the relationship between organizational citizenship behavior and counterproductive work behavior. Journal of Applied Psychology, 90, 12411255. 
Eagly, A. H., \& Wood, W. (1982). Inferred sex differences in status as a determinant of gender stereotypes about social influence. Journal of Personality and Social Psychology, 43, 915-928.

Fox, S., \& Spector, P. E. (Eds.). (2005). Counterproductive work behavior: Investigations of actors and targets. Washington, D.C.: American Psychological Association.

Fragale, A. R., Rosen, B., Xu, C., \& Merideth, I. (2009). The higher they are, the harder they fall: The effects of wrongdoer status on observer punishment recommendations and intentionality attributions. Organizational Behavior and Human Decision Processes, 108, 53-65.

Galinsky, A. D., Gruenfeld, D. H., \& Magee, J. C. (2003). From power to action. Journal of Personality and Social Psychology, 85, 453-466.

Galinsky, A. D., Magee, J. C., Gruenfeld, D. H, Whitson, J. A., \& Liljenquist, K. A. (2008). Social power reduces the strength of the situation: Implications for creativity, conformity, and dissonance. Journal of Personality and Social Psychology, 95, 1450-1466.

Giacalone, R. A., \& Greenberg, J. (Eds.). (1997). Antisocial behavior in organizations. Thousand Oaks, CA: Sage.

Giordano, P. C. (1983). Sanctioning the high-status deviant: An attributional analysis. Social Psychology Quarterly, 46, 329-342.

Goldberg, L. R. (1990). An alternative "description of personality": The Big-Five factor structure. Journal of Personality and Social Psychology, 59, 1216-1229.

Hollander, E. P. (1958). Conformity, status, and idiosyncracy credit. Psychological Review, 65, $117-127$.

Homans, G. C. (1950). The human group. New York: Harcourt Brace. 
Keltner, D., Gruenfeld, D. H., \& Anderson, C. (2003). Power, approach, and inhibition. Psychological Review, 110, 265-284.

Kohn, M. L. (1977). Class and conformity: A study in values (2nd ed.). Chicago: University of Chicago.

Magee, J. C., \& Galinsky, A. (2008). Social hierarchy: The self-reinforcing nature of power and status. In J. P. Walsh \& A. P. Brief (Eds.), Academy of Management Annals (Vol. 2). New York: Lawrence Erlbaum Associates.

Marques, J. M., Yzerbyt, V. Y., \& Leyens, J.-P. (1988). The 'Black Sheep Effect': Extremity of judgments towards ingroup members as a function of group identification. European Journal of Social Psychology, 18, 1-16.

Marx, K., \& Engels, F. (1994). Materialism and the theory of ideology. In R. Collins (Ed.), Four sociological traditions: Selected readings. New York: Oxford University Press.

Mullen, B., Brown, R., \& Smith, C. (1992). Ingroup bias as a function of salience, relevance, and status: An integration. European Journal of Social Psychology, 22, 103-122.

Pettigrew, T. F. (1979). The ultimate attribution error: Extending Allport's cognitive analysis of prejudice. Personality and Social Psychology Bulletin, 5, 461-476.

Pratto, F., Sidanius, J., Stallworth, L. M., \& Malle, B. F. (1994). Social dominance orientation: A personality variable predicting social and political attitudes. Journal of Personality and Social Psychology, 67, 741-763.

Ridgeway, C. L. (2001). The emergence of status beliefs: From structural inequality to legitimizing ideology. In J. Jost \& B. Major (Eds.), The psychology of legitimacy: Emerging perspectives on ideology, justice and intergroup relations (pp. 257-277). New York: Cambridge University Press. 
Robinson, S. L., \& Bennett, R. J. (1995). A typology of deviant workplace behaviors: A multdimensional scaling study. Academy of Management Journal, 38, 555-572.

Schur, E. M. (1983). Labeling women deviant: Gender, stigma, and social control. Philadelphia: Temple University Press.

Sidanius, J., \& Pratto, F. (2001). Social dominance: An intergroup theory of social hierarchy and oppression. Cambridge, UK: Cambridge University Press.

Vardi, Y., \& Weitz, E. (2004). Misbehavior in organizations: Theory, research and management. Mahwah, NJ: Lawrence Erlbaum. 


\section{FIGURE CAPTIONS}

Figure 1. Studies 2a and 2b: Mean propensity to punish workplace deviance by evaluator status and target status. Error bars indicate $\pm 1 \mathrm{SE}$.

Figure 2. Study 3: Mean propensity to punish workplace deviance by evaluator gender, target gender, and target race for all ten behaviors combined (top) and for the three least serious behaviors (bottom left) and three most serious behaviors (bottom right). Error bars indicate \pm 1 SE. 


\section{Figure 1}

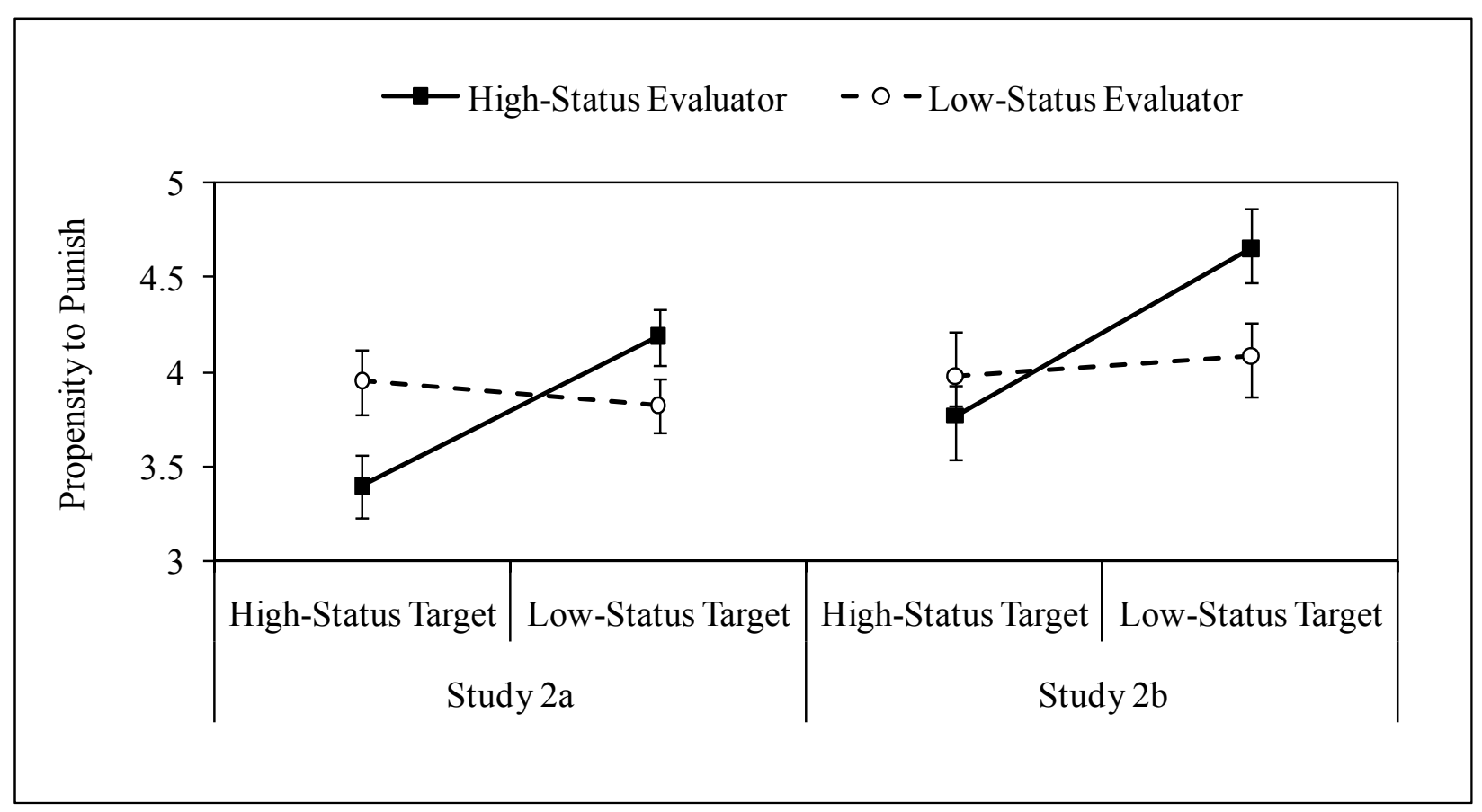


Figure 2

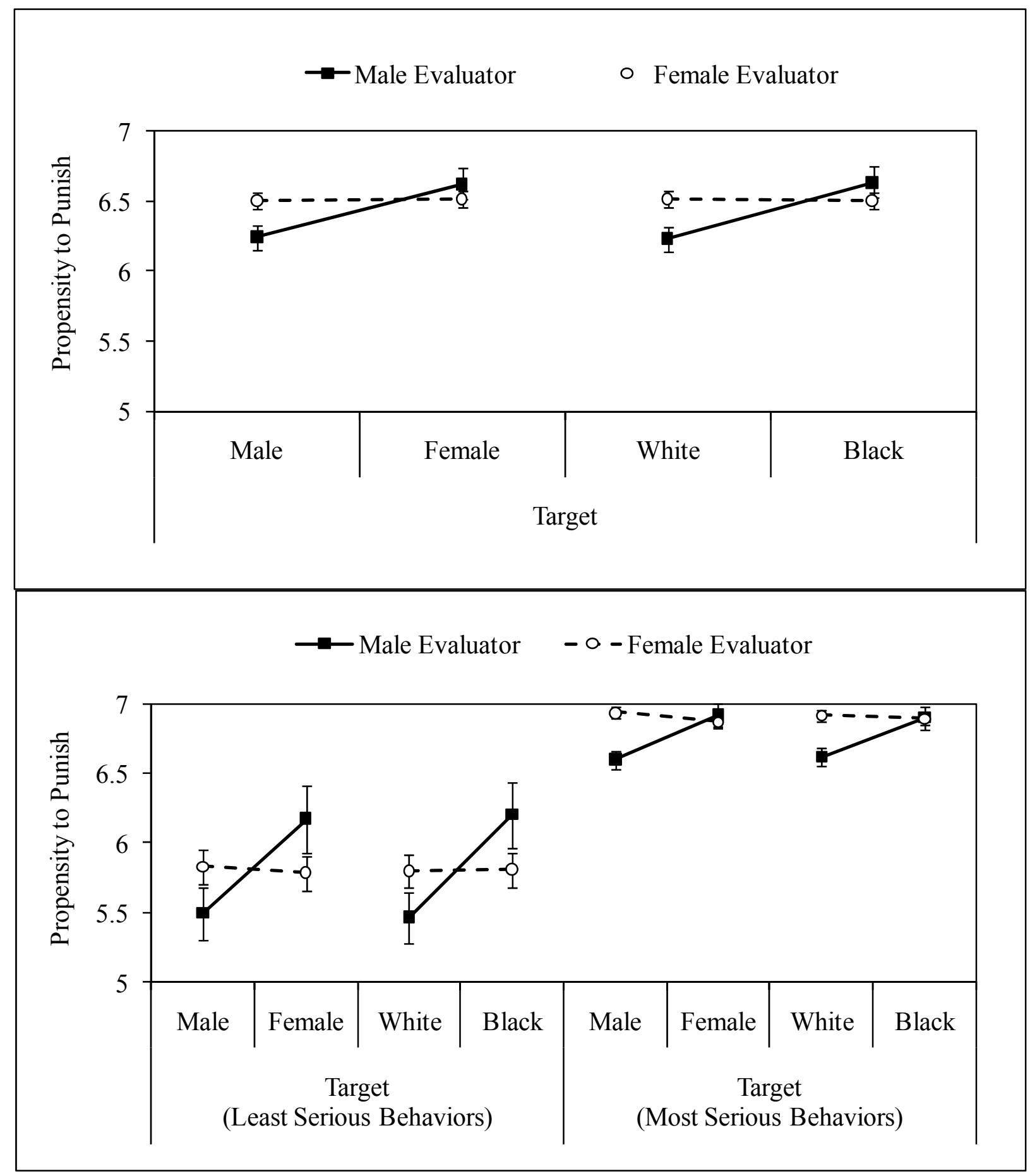

